\title{
Impact of Carcinogenic Chromium on the Cellular Response to Proteotoxic Stress
}

\author{
Leonardo M. R. Ferreira ${ }^{1} \mathbb{D}$, Teresa Cunha-Oliveira ${ }^{2} \mathbb{(}$, Margarida C. Sobral ${ }^{3}$, Patrícia L. Abreu ${ }^{4}$, \\ Maria Carmen Alpoim ${ }^{5}$ and Ana M. Urbano ${ }^{6, *}$ \\ 1 Department of Surgery and Diabetes Center and Sean N. Parker Autoimmune Research Laboratory, \\ University of California, San Francisco, San Francisco, CA 94143, USA; leonardo.ferreira@ucsf.edu \\ 2 CNC-Center for Neuroscience and Cell Biology, University of Coimbra, UC-Biotech, Biocant Park, \\ 3060-197 Cantanhede, Portugal; teresa.oliveira@uc-biotech.pt \\ 3 Department of Life Sciences, University of Coimbra, 3000-456 Coimbra, Portugal; \\ margaridasobral2014@hotmail.com \\ 4 Instituto de Medicina Molecular João Lobo Antunes, Faculty of Medicine, University of Lisbon, \\ 1649-028 Lisbon, Portugal; patricia.abreu@medicina.ulisboa.pt \\ 5 Department of Life Sciences, Center of Investigation in Environment, Genetics and Oncobiology (CIMAGO) \\ and CNC-Center for Neuroscience and Cell Biology, University of Coimbra, 3000-456 Coimbra, Portugal; \\ mcalpoim@gmail.com \\ 6 Department of Life Sciences, Molecular Physical Chemistry Research Unit and Center of Investigation in \\ Environment, Genetics and Oncobiology (CIMAGO), University of Coimbra, 3000-456 Coimbra, Portugal \\ * Correspondence: amurbano@ci.uc.pt
}

Received: 12 August 2019; Accepted: 30 September 2019; Published: 3 October 2019

\begin{abstract}
Worldwide, several million workers are employed in the various chromium $(\mathrm{Cr})$ industries. These workers may suffer from a variety of adverse health effects produced by dusts, mists and fumes containing $\mathrm{Cr}$ in the hexavalent oxidation state, $\mathrm{Cr}(\mathrm{VI})$. Of major importance, occupational exposure to $\mathrm{Cr}(\mathrm{VI})$ compounds has been firmly associated with the development of lung cancer. Counterintuitively, $\mathrm{Cr}(\mathrm{VI})$ is mostly unreactive towards most biomolecules, including nucleic acids. However, its intracellular reduction produces several species that react extensively with biomolecules. The diversity and chemical versatility of these species add great complexity to the study of the molecular mechanisms underlying $\mathrm{Cr}(\mathrm{VI})$ toxicity and carcinogenicity. As a consequence, these mechanisms are still poorly understood, in spite of intensive research efforts. Here, we discuss the impact of $\mathrm{Cr}(\mathrm{VI})$ on the stress response-an intricate cellular system against proteotoxic stress which is increasingly viewed as playing a critical role in carcinogenesis. This discussion is preceded by information regarding applications, chemical properties and adverse health effects of $\mathrm{Cr}(\mathrm{VI})$. A summary of our current understanding of cancer initiation, promotion and progression is also provided, followed by a brief description of the stress response and its links to cancer and by an overview of potential molecular mechanisms of $\mathrm{Cr}(\mathrm{VI})$ carcinogenicity.
\end{abstract}

Keywords: carcinogenesis; hexavalent chromium; heat shock proteins; HSP70; HSP90; HSP inhibitor; occupational lung carcinogen; proteotoxic stress; stress response; unfolded protein response

\section{Hexavalent Chromium: Applications, Chemical Properties and Biological Implications}

Chromium (Cr), a transition metal, is the 21st most abundant chemical element in Earth's crust. It can exist in a variety of oxidation states, from -2 to +6 , but most of these states are too unstable to exist in any significant amount [1]. In nature, $\mathrm{Cr}$ exists mostly in the trivalent oxidation state, $\mathrm{Cr}(\mathrm{III})$, but it can also be found in the hexavalent oxidation state, $\mathrm{Cr}(\mathrm{VI}) . \mathrm{Cr}(\mathrm{VI})$ compounds have a wide range of applications and are extensively used as pigments for textile dyes, paints, inks and plastics, 
corrosion inhibitors, leather tanning agents and wood preservatives, amongst other uses [2,3]. Due to the low natural abundance of $\mathrm{Cr}(\mathrm{VI})$ compounds, all $\mathrm{Cr}(\mathrm{VI})$ used in industrial and commercial applications must be produced from $\mathrm{Cr}(\mathrm{III})$ found in chromite ores.

$\mathrm{Cr}$ (III) compounds are essentially innocuous and are widely used as nutritional supplements [4,5], although their beneficial health effects have been questioned by the European Food Safety Authority [6]. On the contrary, exposure to $\mathrm{Cr}(\mathrm{VI})$ compounds is associated with numerous adverse health effects, mostly to the skin and respiratory system. Importantly, the International Agency for Research on Cancer (IARC), the National Toxicology Program (NTP) and other highly respected regulatory agencies have classified $\mathrm{Cr}(\mathrm{VI})$ compounds as lung carcinogens [7-9].

The highest human exposures to $\mathrm{Cr}(\mathrm{VI})$ occur in the chemical, metallurgical and refractive chrome industries, through dermal contact and inhalation of dusts, mists and/or fumes. In addition, significant exposure can occur during welding, casting and cutting of stainless steel and other chromium-containing metals and alloys, as $\mathrm{Cr}(\mathrm{VI})$ can be given off as a by-product [8]. The general population and the wildlife, particularly those living in the vicinity of chromate industries, may also be exposed through inhalation of ambient air or ingestion of contaminated drinking water. Leaching of wastewater from industrial waste disposal sites and landfills may also contaminate drinking water. In addition, $\mathrm{Cr}(\mathrm{VI})$ compounds are continuously released to ambient air as exhaust emission products in fuel combustion and cigarette smoke. Milling and demolition are additional sources of environmental contamination, as $\mathrm{Cr}(\mathrm{VI})$ compounds are present, as impurities, in Portland cement [3].

The different toxicities of $\mathrm{Cr}(\mathrm{III})$ and $\mathrm{Cr}(\mathrm{VI})$ compounds can be rationalized in terms of their physico-chemical properties. Namely, their ability to cross biological membranes and, ultimately, induce intracellular damage is determined by their sizes, structures and charges. At physiological $\mathrm{pH}$, $\mathrm{Cr}(\mathrm{VI})$ exists mostly as chromate anions $\left(\mathrm{CrO}_{4}{ }^{2-}\right)$. Being isostructural with the sulfate and phosphate anions, the chromate anions released from $\mathrm{Cr}(\mathrm{VI})$ compounds move easily across cellular membranes using the anion transport system $[10,11]$. By contrast, the larger size and octahedral structure of the $\mathrm{Cr}$ (III) ions prevent them from using this transport system. Still, a very small fraction of insoluble $\mathrm{Cr}$ (III) salts are taken up by the cells, mostly by phagocytosis [12]. Poorly water-soluble chromates with a particle size of less than $5 \mu \mathrm{m}$ can also be phagocytosed and will gradually dissolve in the intracellular milieu [8].

Postmortem microscopic analysis of lung tissue and biopsy samples from chromate industry workers revealed that particulate $\mathrm{Cr}(\mathrm{VI})$ compounds tend to deposit at the bronchial bifurcations [13-15]. Postmortem studies further showed that tumors tend to develop centrally in the lung, with the most frequent histological type of $\mathrm{Cr}(\mathrm{VI})$-induced lung cancer being squamous cell carcinoma [16]. Thus, it has been argued that $\mathrm{Cr}(\mathrm{VI})$ compounds are particularly dangerous when inhaled in the form of particulates, as their slow and constant dissolution ensures a long lasting exposure of lung epithelial cells to chromates. However, as an excess risk of lung cancer was observed among workers exposed to $\mathrm{Cr}(\mathrm{VI})$ compounds of diverse solubilities, it is likely that all $\mathrm{Cr}(\mathrm{VI})$ compounds are endowed with a similar carcinogenic potential [8].

Suspicions of a link between $\mathrm{Cr}$ exposure and lung cancer were first raised in the late nineteenth century, when an increased incidence of this type of cancer was observed among Scottish chrome pigment workers [17]. Since then, evidence in favor of this link has steadily accumulated. Yet, it was only in the 1980s that $\mathrm{Cr}$, more specifically $\mathrm{Cr}(\mathrm{VI})$, was firmly established as a human lung carcinogen. This classification triggered an intense search for the cellular and molecular mechanisms underlying $\mathrm{Cr}(\mathrm{VI})$-induced lung cancer. Naturally, the lines of research followed over time have been influenced by contemporary theories of carcinogenesis. For contextualization, our current understanding of cancer initiation, promotion and progression will be briefly discussed in the next section, with an emphasis on the roles played by different stresses. 
2. Cancer Initiation, Promotion and Progression: The Critical Importance of Oxidative, Proteotoxic and Genotoxic Stresses

According to the current paradigm, carcinogenesis is driven by stepwise genetic mutations and concomitantly enhanced and uncontrolled cell proliferation. DNA damage is believed to be in the genesis of this process by creating a transformed cell, which over the course of additional genomic and cellular insults becomes a fully malignant and metastatic cancer cell [18]. In spite of the creation of elaborate genetic mouse cancer models [19] and large-scale sequencing efforts for many cancer types [20], the process of carcinogenesis remains, for the most part, poorly understood.

Traditionally, carcinogenesis has been divided into three phases: initiation, promotion and progression [21] (Figure 1). Initiation entails the acquisition of mutations in proto-oncogenes and tumor suppressor genes. Significantly, incipient cancer cells feature a deranged metabolism, leading to high levels of reactive oxygen species (ROS) and, consequently, oxidative stress [22-25] (Figure 1). ROS damage not only DNA, but also proteins and membrane lipids. Yet, ROS also play a role in cellular signaling, promoting cell proliferation and adaptation to the hypoxic conditions often found in the tumor microenvironment [26]. In particular, mitochondrial ROS inactivate inhibitory phosphatases (e.g., PTEN), unleashing the PI3K/AKT cell survival and growth pathway, and prolyl hydroxylases (e.g., PHD2). In turn, this inactivation stabilizes hypoxia inducible factors (HIF), concomitantly triggering angiogenesis. Next, cancer cells enter a promotion phase, when mutations in oncoproteins such as growth factor receptors and kinases gradually lead to independence from extracellular growth factors [27]. As mutations often disrupt a protein's ability to fold [28], accumulation of increasingly larger amounts of mutated proteins represents yet another type of cell intrinsic stress-proteotoxic stress [29] (Figure 1). This type of stress can be created by any structural alteration that may lead to protein misfolding and aggregation. Ultimately, incipient cancer cells form a solid tumor mass, creating with it a tumor microenvironment. Here, cancer cells reprogram stromal cells to produce tumorigenic cytokines, chemokines and tissue-remodeling metalloproteinases [30], inhibit anticancer immune responses [31] and recruit blood vessels via angiogenesis to sustain their continued growth [32]. The tumor microenvironment also creates a host of cell extrinsic stressors, including hypoxia, acidosis and nutrient deprivation [33-36]. Malignant tumors are also characterized by rampant chromosomal instability and aneuploidy, caused by chromosome segregation errors during mitosis. Such extensive damage leads to genotoxic stress. While genotoxic stress leads to p53-induced apoptosis in normal cells, in malignant cells it is tolerated and subverted, giving rise to a mosaic of genomic mutations and karyotypic abnormalities in solid tumors [37-39]. 


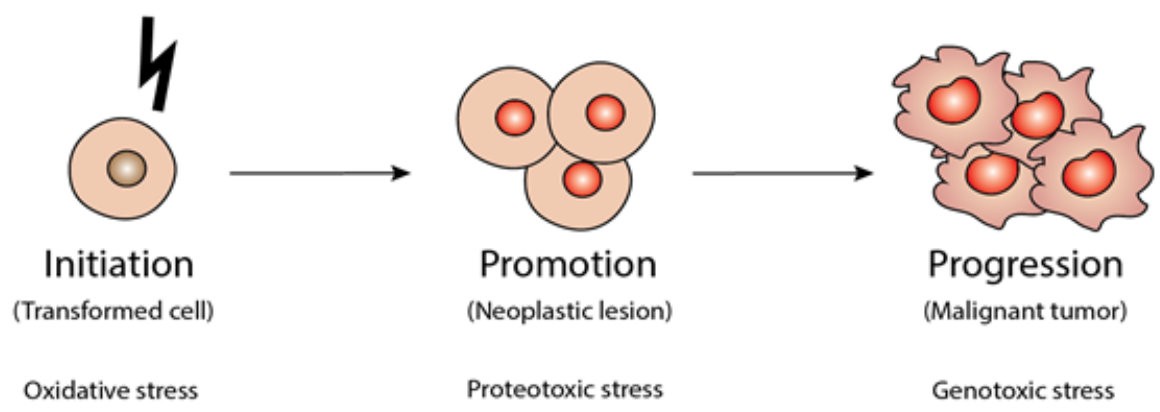

Figure 1. The different types of stress associated with the three stages of carcinogenesis. Carcinogenesis has been traditionally divided in three stages: initiation, promotion and progression. Different types of cellular stress have been implicated in these stages. Oxidative stress and reactive oxygen species (ROS) damage proteins and membranes, and induce DNA mutations. Incipient cancer cells at the promotion stage harbor an increasing number of DNA mutations, resulting in dramatically higher levels of mutant proteins that induce proteotoxic stress. Transition to a fully malignant phenotype, i.e., progression, is thought to require chromosomal instability and resulting karyotypic abnormalities, inducing genotoxic stress. Of note, all types of stress indicated (oxidative, proteotoxic and genotoxic) play roles in all three stages of carcinogenesis described above; their relative importance likely differs amongst different types of cancer.

\section{Links between the Cellular Response to Stress and Carcinogenesis}

Carcinogenesis entails the acquisition of a growing ability to survive in the face of cellular stress levels that normal cells are unable to withstand. There is now a growing perception that this ability results, at least in part, from a subversion of the cellular systems that evolved to protect normal cells against stress. This section will briefly describe one of these systems, the so-called stress response, a homeostatic system to combat proteotoxic stress that is found across all three domains of life [40]. It also includes a discussion of the links between the stress response and cancer.

\subsection{Note on Nomenclature}

Several of the studies discussed in this review were carried out at a time when very little was known regarding heat shock proteins (HSP) and their role in the cellular response to stress. Back then, HSP were named based on their approximate subunit molecular weights, as determined by polyacrylamide gel electrophoresis. For instance, the designations Hsp90 and HSP90 were used interchangeably to describe any protein with an approximate subunit molecular weight of $90 \mathrm{kDa}$ whose expression was rapidly and strongly induced by stress. Since then, the number of known stress-responsive proteins, some of which constitutively expressed, has expanded enormously. Many of the now known isoforms share identical subunit molecular weights and it is often not possible to retrospectively identify the specific isoform(s) being described in the earlier studies. In this review, we use the abbreviation Hsp when referring to a clearly identified isoform (e.g., Hsp72), whilst HSP abbreviates either one or more unspecified isoforms of a given family or the family as a whole (e.g., HSP90 will be used to describe an unidentified isoform of an approximate subunit molecular weight of $90 \mathrm{kDa}$ or the HSP90 family as a whole).

To complicate matters further, as some stress-responsive proteins were not initially classified as HSP; they were given unrelated names. Currently, up to ten different names can be found in the literature for the same gene product [41]. Aiming at reducing inconsistencies and increase clarity, Kampinga and collaborators put forward, already in 2009, new guidelines for the nomenclature of the human HSP [41]. Unfortunately, this nomenclature has not yet been widely adopted, remaining unfamiliar to most readers. In Table 1, which summarizes all studies covered in this review on the impact of $\mathrm{Cr}(\mathrm{VI})$ on components of the stress response, genes and gene products are presented as found 
in the corresponding papers. Nonetheless, whenever an unambiguous identification was possible, the new nomenclature was added, between brackets, following the name used in the original paper.

Table 1. Cr(VI)-induced effects on the expression and activity of components of the stress response.

\begin{tabular}{|c|c|c|c|c|c|}
\hline \multirow[b]{2}{*}{ Protein Family } & \multirow[b]{2}{*}{ System $^{1}$} & \multicolumn{2}{|c|}{ Exposure Regime } & \multirow[b]{2}{*}{ Effect $^{3}$} & \multirow[b]{2}{*}{ Study } \\
\hline & & $\begin{array}{c}\mathrm{Cr}(\mathrm{VI}) \\
\text { Dose/Concentration }^{2}\end{array}$ & Duration & & \\
\hline \multirow{6}{*}{ Small HSP } & $\begin{array}{c}\text { Rat lung } \\
\text { epithelial cells }\end{array}$ & $10 \mu \mathrm{M}$ & $24 \mathrm{~h}$ & $\begin{array}{c}\text { Increased HSP10 protein } \\
\text { levels }\end{array}$ & [42] \\
\hline & $\mathrm{HaCaT}$ cells & $7.4 \mu \mathrm{M}$ & $24 \mathrm{~h}$ & $\begin{array}{c}\text { Increased HSP27 (HSPB1) } \\
\text { mRNA and protein levels; } \\
\text { Reduced HSP27 (HSPB1) } \\
\text { phosphorylation }\end{array}$ & [43] \\
\hline & $\begin{array}{c}\text { Human } \\
\text { primary skin } \\
\text { fibroblasts }\end{array}$ & $1 \mu \mathrm{M}$ & $16 \mathrm{~h}$ & $\begin{array}{l}\text { Increased protein levels of } \\
\text { phosphorylated HSP27 }\end{array}$ & [44] \\
\hline & BNL CL. 2 cells & $15 \mu \mathrm{M}$ & $3 \mathrm{~h}$ & \multirow[b]{2}{*}{$\begin{array}{l}\text { Increased liver HSP27 } \\
\text { protein levels }\end{array}$} & \multirow[b]{2}{*}{ [45] } \\
\hline & ICR mice & $\begin{array}{l}10 \mathrm{mg} / \mathrm{kg} \text { body weight } \\
\text { (intraperitoneal } \\
\text { injection) }\end{array}$ & 8 weeks & & \\
\hline & BEAS-2B cells & $10 \mu \mathrm{M}$ & $4 \mathrm{~h}$ & $\begin{array}{c}\text { Unchanged HSP27 } \\
\text { (HSPB1) mRNA levels }\end{array}$ & [46] \\
\hline Hsp40 & BEAS-2B cells & \multirow{3}{*}{$10 \mu \mathrm{M}$} & $4 \mathrm{~h}$ & $\begin{array}{l}\text { Decreased HSP40 mRNA } \\
\text { levels }\end{array}$ & \multirow{2}{*}{ [46] } \\
\hline \multirow{2}{*}{ HSP60 } & BEAS-2B cells & & $4 \mathrm{~h}$ & $\begin{array}{c}\text { Decreased HSP60 (HSPD1) } \\
\text { mRNA levels }\end{array}$ & \\
\hline & $\begin{array}{c}\text { Rat lung } \\
\text { epithelial cells }\end{array}$ & & $24 \mathrm{~h}$ & $\begin{array}{l}\text { Increased HSP60 protein } \\
\text { levels }\end{array}$ & [42] \\
\hline \multirow{7}{*}{ HSP70 } & \multirow{2}{*}{ BEAS-2B cells } & $1 \mu \mathrm{M}$ & $48 \mathrm{~h}$ & $\begin{array}{c}\text { Unchanged Hsp72 } \\
\text { (HSPA1A) protein levels; } \\
\text { Decreased Hsp72 } \\
\text { (HSPA1A) mRNA levels }\end{array}$ & [47] \\
\hline & & $10 \mu \mathrm{M}$ & $4 \mathrm{~h}$ & $\begin{array}{c}\text { Unchanged HSP70 } \\
\text { (HSPA6), HSP70.1 (HSPA1) } \\
\text { and HSP71 (HSPA8) } \\
\text { mRNA levels }\end{array}$ & [46] \\
\hline & $\begin{array}{l}\text { Sprague-Dawley } \\
\text { rats }\end{array}$ & $\begin{array}{c}0.25 \mathrm{mg} / \mathrm{kg} \text { body } \\
\text { weight (intratracheal } \\
\text { instillation) }\end{array}$ & 3 days & $\begin{array}{l}\text { HSP70 mRNA levels } \\
\text { increased in the lungs and } \\
\text { unchanged in the liver; } \\
\text { Unchanged HSP60, Grp75 } \\
\text { and Grp94 mRNA levels } \\
\text { in both lungs and liver }\end{array}$ & [48] \\
\hline & HT29 & 10 or $50 \mu \mathrm{M}$ & $6 \mathrm{~h}$ & Increased Hsp72 & [49] \\
\hline & & 0.5 or $1 \mu \mathrm{M}$ & 01 & (HSPA1A) mRNA levels & \\
\hline & HepG2 cells & $0.625-10 \mu \mathrm{M}$ & $48 \mathrm{~h}$ & $\begin{array}{l}\text { Induction of HSP70 and } \\
\text { Grp78 (HSPA5) promoters } \\
\text { for }[\mathrm{Cr}(\mathrm{VI})] \geq 5 \mu \mathrm{M}\end{array}$ & [50] \\
\hline & & $100 \mu \mathrm{M}$ & $3 \mathrm{~h}$ & $\begin{array}{c}\text { Unchanged HSP70 mRNA } \\
\text { levels }\end{array}$ & [51] \\
\hline
\end{tabular}


Table 1. Cont.

\begin{tabular}{|c|c|c|c|c|c|}
\hline \multirow[b]{2}{*}{ Protein Family } & \multirow[b]{2}{*}{ System $^{1}$} & \multicolumn{2}{|c|}{ Exposure Regime } & \multirow[b]{2}{*}{ Effect $^{3}$} & \multirow[b]{2}{*}{ Study } \\
\hline & & $\begin{array}{c}\mathrm{Cr}(\mathrm{VI}) \\
\text { Dose/Concentration }^{2}\end{array}$ & Duration & & \\
\hline & $\begin{array}{l}\text { Primary culture } \\
\text { of rat granulosa } \\
\text { cells }\end{array}$ & $10 \mu \mathrm{M}$ & 12 or $24 \mathrm{~h}$ & $\begin{array}{c}\text { Decreased HSP70 protein } \\
\text { levels }\end{array}$ & [52] \\
\hline & \multirow[t]{2}{*}{ L-02 cells } & 16 or $32 \mu \mathrm{M}$ & $24 \mathrm{~h}$ & $\begin{array}{c}\text { Decreased HSP70 proteins } \\
\text { levels }\end{array}$ & [53] \\
\hline & & 8 or $16 \mu \mathrm{M}$ & $24 \mathrm{~h}$ & $\begin{array}{c}\text { Increased Grp78 (HSPA5) } \\
\text { mRNA levels }\end{array}$ & {$[54]$} \\
\hline & BNL CL. 2 cells & $15 \mu \mathrm{M}$ & $3 \mathrm{~h}$ & \multirow[b]{2}{*}{$\begin{array}{l}\text { Increased liver HSP70 } \\
\text { protein levels }\end{array}$} & \multirow{2}{*}[45]{} \\
\hline & ICR mice & $\begin{array}{c}10 \mathrm{mg} / \mathrm{kg} \text { body weight } \\
\text { (intraperitoneal } \\
\text { injection) }\end{array}$ & 8 weeks & & \\
\hline & A549 & $0.5 \mu \mathrm{M}$ & $2-24 \mathrm{~h}$ & $\begin{array}{c}\text { Increased Grp78 (HSPA5) } \\
\text { protein levels }\end{array}$ & [55] \\
\hline \multirow{5}{*}{ HSP90 } & \multirow{2}{*}{ BEAS-2B cells } & $1 \mu \mathrm{M}$ & $48 \mathrm{~h}$ & $\begin{array}{c}\text { Decreased Hsp90 } \alpha \\
\text { (HSPC1) protein levels. } \\
\text { Unchanged Hsp } 90 \alpha \\
\text { (HSPC1) mRNA levels }\end{array}$ & {$[47]$} \\
\hline & & \multirow[b]{2}{*}{$10 \mu \mathrm{M}$} & $4 \mathrm{~h}$ & $\begin{array}{c}\text { Decreased HSP90A } \\
\text { (HSPC1) mRNA levels }\end{array}$ & [46] \\
\hline & $\begin{array}{l}\text { Primary culture } \\
\text { of rat granulosa } \\
\text { cells }\end{array}$ & & 12 or $24 \mathrm{~h}$ & $\begin{array}{c}\text { Decreased HSP90 protein } \\
\text { levels }\end{array}$ & {$[52]$} \\
\hline & L-02 cells & 16 or $32 \mu \mathrm{M}$ & $24 \mathrm{~h}$ & $\begin{array}{c}\text { Decreased HSP90 protein } \\
\text { levels }\end{array}$ & {$[53]$} \\
\hline & A549 & $600 \mu \mathrm{M}$ & $2 \mathrm{~h}$ & $\begin{array}{c}\text { Increased TRAP1 (HSPC5) } \\
\text { mRNA levels }\end{array}$ & [56] \\
\hline HSP100 & $\begin{array}{l}\text { Rat lung } \\
\text { epithelial cells }\end{array}$ & $10 \mu \mathrm{M}$ & $24 \mathrm{~h}$ & $\begin{array}{c}\text { Increased HSP105 protein } \\
\text { levels }\end{array}$ & {$[42]$} \\
\hline
\end{tabular}

1 A549, cell line established from a human lung adenocarcinoma; BEAS-2B, cell line established from human bronchial epithelium; BNL CL.2, cell line established from embryonic murine liver tissue; HaCaT, keratinocytes cell line established from human skin; HepG2, cell line established from a human hepatocellular carcinoma; HT29, cell line established from a human colorectal adenocarcinoma; L-02, cell line established from human embryonic liver tissue. ${ }^{2} \mathrm{Cr}(\mathrm{VI})$ was added as a $\mathrm{K}_{2} \mathrm{Cr}_{2} \mathrm{O}_{7}$ or $\mathrm{Na}_{2} \mathrm{CrO}_{4}$ aqueous solution. Of note, for several studies, $\mathrm{Cr}(\mathrm{VI})$ concentration values are ambiguous, as the expressions " $x \mu \mathrm{M} \mathrm{Cr}(\mathrm{VI})$ " and " $x \mu \mathrm{M}$ potassium dichromate" were used indistinguishably, even though a given potassium dichromate concentrations corresponds to a $\mathrm{Cr}(\mathrm{VI}) \mathrm{concentration}$ twice that value. ${ }^{3}$ For designations, see Section 3.1.

\subsection{The Stress Response: Basic Concepts}

The cytoprotective effects of the stress response are mediated by the heat shock proteins (HSP). These molecular chaperones promote proper protein folding, translocation and degradation, as well as the assembly and disassembly of protein complexes $[57,58]$. In mammals, heat shock factor 1 (HSF1) is the main transcriptional regulator of the stress response [59,60].

In eukaryotic cells, the stress response comprises different sub-systems, which fulfil organelle-specific functions, such as the unfolded protein response (UPR), which operates in the endoplasmic reticulum (ER) [61], and the mitochondrial unfolded protein response (UPRmt). The ER is a major site for the synthesis, folding, modification and transport of secretory and transmembrane proteins, as well as for the assembly of protein complexes [62,63]. Incorrect protein maturation can occur even under physiological conditions, due to, among other causes, the very high protein concentrations normally found in the ER $(\sim 100 \mathrm{mg} / \mathrm{mL}[64,65])$. ER stress, i.e., the incapacity of this organelle to manage its load of client proteins, is further aggravated under conditions of nutrient deprivation, hypoxia, augmented ROS levels and acidic extracellular milieu, amongst others [66]. Of note in the context of the present review, these conditions are often found in the tumor microenvironment. Furthermore, 
certain cancers, such as the B cell-derived malignancy multiple myeloma, produce extremely high levels of immunoglobulins, which translates into protein overload and consequent ER stress [67].

Accumulation of unfolded or misfolded proteins triggers the UPR, which signals transient attenuation of protein translation, while increasing the ER capacity of protein folding and degradation of misfolded proteins $[64,65,68]$. Amongst the molecular chaperones involved in the re-establishment of protein homeostasis (i.e., proteostasis) are numerous glucose-regulated proteins (induced by glucose starvation), including Grp78, which is the most abundant ER-resident chaperone, and Grp94 [64,65,68-70]. Grp78 and Grp94 are the ER homologues of, respectively, HSP70 and HSP90 proteins. After a certain time, proteins that remain aggregated, misfolded and/or unassembled are targeted for ER-associated degradation (ERAD), leading to their translocation from the ER to the cytosol to be degraded by the ubiquitin-proteasome machinery [71]. If ER stress becomes chronic, abnormal calcium signaling from ER to mitochondria and apoptotic pathways can be activated [72].

In eukaryotes, the metabolic energy required to sustain cellular processes, including stress-induced adaptations, is generated mostly in the mitochondria. Interestingly, mitochondria are closely connected to the ER through mitochondria-associated membranes (MAMs), which allow the exchange between these two organelles of lipids, calcium ions $\left(\mathrm{Ca}^{2+}\right)$ and, possibly, ROS. It has also been suggested that MAMs are involved in glucose homeostasis [73]. ER and mitochondrial stress pathways seem to be interconnected, as a mitochondria resident HSP90, tumor necrosis factor receptor-associated protein 1 (TRAP1), has been associated with UPR in the ER [74,75]. Also, p53-upregulated PUMA and NOXA [76] and Lon protease [77], which is also a chaperone [78], seem to be part of a signaling pathway that transmits ER dysfunction to the mitochondria. ER stress, amino acid depletion, excessive ROS levels, oxidative phosphorylation (OXPHOS) perturbation, impaired complex assembly (mitonuclear protein imbalance) and the accumulation of misfolded proteins impair mitochondrial protein import efficiency and lead to nuclear translocation of the activating transcription factor associated with stress (ATF) and subsequent activation of the UPRmt [79-81]. In the nucleus, ATF mediates the transcription of genes involved in the re-establishment of mitochondrial function, mitochondrial proteostasis and protein import efficiency [82,83]. Resistance to ER and mitochondrial stresses can contribute to carcinogenesis [84,85].

\subsection{Cancer and the Stress Response}

It has been known for some time that most types of tumors display augmented HSP levels [86]. Increased HSF1 activity likely contributes to the augmented HSP levels, yet it has been reported that HSP gene promoters can also be activated by the oncogenic transcription factor c-MYC, as well as by loss of the tumor suppressor protein p53 [87]. Strikingly, deletion of HSF1 in mice bearing mutations in the Ras oncogene and Tp53 tumor suppressor gene protected them from tumor formation [88].

Specific HSP have been directly implicated in p53 inactivation and malignant transformation [89], as well as in cancer invasiveness and resistance to chemotherapy [90]. For instance, HSP90 overexpression, which was observed in a broad spectrum of cancers, correlated with tumor growth, metastatic potential and resistance to chemotherapy $[86,91,92]$. This observation led to the proposal that tumors develop an "addiction" to HSP90 [93,94]. It is noteworthy that, unlike other HSP, HSP90 proteins are not necessary for the correct folding of newly synthesized proteins. Instead, their main role is to stabilize meta-stable proteins, ultimately suppressing the formation of protein aggregates. Importantly, numerous oncoproteins are HSP90 clients [95]. Chief among these are several receptor tyrosine kinases and steroid hormone receptors, such as the human epidermal growth factor 2 (HER2), associated with uncontrolled cellular proliferation [92,96], telomerase, an enzyme required for immortalization [97], AKT, involved in the deregulation of the apoptosis [98], hypoxia-inducible factor 1-alpha (HIF-1 $\alpha$ ), essential for angiogenesis [99] and the metabolic shift observed in tumors [22,92,100], and matrix metalloproteinases (MMPs), crucial for successful tissue invasion and metastasis [101]. According to the "HSP90 addiction hypothesis", cancer cells need an increased pool of HSP90. This increased pool is critical to retrieve essential proteins that became misfolded due to extensive proteotoxic stress 
and to allow increasingly more mutated oncoproteins and tumor suppressor proteins to function, by preventing their misfolding and degradation.

Remarkably, HSP90 proteins have also been found in the extracellular milieu, where they act as potent stimulators of immune responses [102]. Unsurprisingly, HSP90 is currently being explored as a target for cancer therapy. There are currently 73 clinical trials employing HSP90 inhibitors registered in ClinicalTrials.gov. Nevertheless, no HSP90 inhibitor has been approved for cancer treatment yet [103].

Altogether, the stress response emerges as a double-edged sword: evolved to protect cells from menaces to homeostasis, it might constitute, in its extreme, one of the main mechanisms behind cancer cells' formidable resilience. Several questions remain open. How much cellular stress is required for it to have an impact on carcinogenesis? Do qualitatively different levels of stress play distinct roles in cancer? HSP activation is exquisitely sensitive to cellular stress-inducing agents. Studying the links between the stress response and carcinogenesis will answer these and other questions and contribute to a more detailed understanding of cancer.

\section{The Molecular Mechanisms of Hexavalent Chromium Carcinogenicity: A Brief State of the Art}

Genetic and epigenetic mechanisms likely play a critical role $\mathrm{Cr}(\mathrm{VI})$ carcinogenesis. This view is supported by the observation of genetic lesions in both the lung cells of chromate workers and in cultured cells exposed to different $\mathrm{Cr}(\mathrm{VI})$ concentrations $[11,13,15,16,104-109]$. Thus, the initial observation, in test tube experiments, that $\mathrm{Cr}(\mathrm{VI})$ is mostly unreactive towards DNA (and most other biomolecules) puzzled researchers. However, it is now known that, following its rapid cellular uptake, $\mathrm{Cr}(\mathrm{VI})$ undergoes a multi-step reduction that generates a variety of species that react extensively with biomolecules, namely $\mathrm{Cr}(\mathrm{III})$, which is the final reduction species, and the unstable intermediates $\mathrm{Cr}(\mathrm{IV})$ and $\mathrm{Cr}(\mathrm{V})[110,111]$. Under physiological conditions, ascorbate accounts for about $90 \%$ of $\mathrm{Cr}(\mathrm{VI})$ reduction, but non-protein thiols, such as glutathione and cysteine, also contribute significantly to its reduction [112]. Thus, $\mathrm{Cr}(\mathrm{VI})$ reduction generates additional reactive species, such as carbon-based radicals from ascorbate, and thiyl radicals from glutathione and cysteine. The generation of ROS $[113,114]$ is still a matter of debate, as it has been argued that the methods employed for detection of $\mathrm{Cr}(\mathrm{VI})$-induced $\mathrm{ROS}$ were not adequate and that the $\mathrm{Cr}(\mathrm{VI})$ concentrations employed in those studies were too high to be of biological relevance [115]. Among the $\mathrm{Cr}$ (III)-DNA complexes formed are Cr(III)-DNA adducts, DNA-protein crosslinks and DNA interstrand crosslinks [11,115].

$\mathrm{Cr}(\mathrm{VI})$ exposure can result in DNA damage by both direct and indirect mechanisms. For instance, $\mathrm{Cr}(\mathrm{VI})$ exposure may lead to loss of thiol redox control through interference with antioxidant defense systems [116]. This and additional lines of evidence, namely the observation of 8-hydroxy-2'-deoxyguanosine formation in rat lungs following intratracheal administration of $\mathrm{Cr}(\mathrm{VI})$ [108], suggest that $\mathrm{Cr}(\mathrm{VI})$ exposure can damage DNA through the generation of oxidative stress [50,117,118]. Additionally, altered ROS levels affect gene expression [119].

DNA damage can also result from a direct interaction of these biomolecules with $\mathrm{Cr}(\mathrm{III})$, generating different types of $\mathrm{Cr}(\mathrm{III})$-DNA adducts. By restraining the normal DNA replication and transcription processes, these adducts activate the various cellular DNA repair systems in a lesion-dependent manner. Cr-DNA monoadducts are preferentially repaired by the base excision repair (BER) system in coordination with the apurinic/apyrimidinic (AP) site repair system [120]. The transient single-strand breaks (SSB) that are formed are then promptly repaired by the cooperative action of DNA polymerase $\beta(\operatorname{Pol} \beta)$ and the X-ray cross-complementing group 1 (XRCC1) complex [121]. Cr(III)-DNA-protein crosslinks and DNA inter/intrastrand crosslinks (ICLs) require recruitment of other DNA repair systems, namely the nucleotide excision repair (NER) system [122]. Mutations in key proteins involved in these DNA repair systems have been described both in $\mathrm{Cr}(\mathrm{VI})$-induced lung cancer patients and in cultured cells exposed to $\mathrm{Cr}(\mathrm{VI})$ compounds, impairing their ability to remove chromium-DNA adducts [122]. In addition to SSB formation, double-strand break (DSB) induction by the mismatch repair (MMR) system may drive genomic instability, either as a direct result of the repair systems or due to delayed repair and concomitant cell cycle arrest which, in the case of $\mathrm{Cr}(\mathrm{VI})$, often uncouples karyokinesis 
from cytokinesis [3,123]. Hirose and co-workers reported a high incidence of microsatellite instability (MSI), a particular type of genomic instability that specifically affects the microsatellites, in lung cancers from chromate-exposed workers [3,124,125]. However, a similar finding could not be observed upon in vitro exposure of human lung epithelial cells to $\mathrm{Cr}$ (VI) [126].

Unsurprisingly, the impact of $\mathrm{Cr}(\mathrm{VI})$ on the signaling pathways that underlay cell proliferation, differentiation and death has been the focus of multiple research studies, but a clear picture is yet to emerge. While an in-depth discussion of these studies is beyond the scope of this review, it is noteworthy that the sequences targeted in $\mathrm{Cr}$ (III)-DNA and $\mathrm{Cr}$ (III)-histidine-DNA lesions in the TP53 gene are identical, with both types of adducts formed at-NGG- sequences at mutational hotspots in lung cancer. These findings suggest that $\mathrm{Cr}$ (III)-DNA adduct formation contributes to the TP53 mutations observed in lung carcinogenesis [127].

Cancer has been traditionally viewed as a genetic disease, but it is now increasingly clear that non-genetic events can also be critical players in carcinogenesis. For instance, $\mathrm{Cr}(\mathrm{VI})$-induced lesions may contribute to the onset of inflammatory lung disease, which in turn predisposes to lung cancer, as illustrated by the strong correlation between lung cancer and both bronchitis and interstitial lung diseases $[128,129]$. In line with this hypothesis, it was reported that zinc chromate nanoparticles induce bronchiolar cell apoptosis and mucosal injury, later progressing to alveolar and interstitial pneumonitis. It was also found that inflammatory cytokines, such as IL- 6 and TNF- $\alpha$, and activation of the survival pathway AKT were involved $[120,122-125,127,128,130,131]$. Another study revealed that, in vitro, progression to higher malignant states in $\mathrm{Cr}(\mathrm{VI})$-induced carcinogenesis is mediated by the inflammatory cytokines IL-6 and G-CSF and Activin A released by stromal cells, with the concomitant activation of STAT3 and WNT signaling pathways [132].

\section{The Impact of Hexavalent Chromium on the Stress Response}

As mentioned previously, there is a growing perception that the stress response may be a critical player in carcinogenesis. $\mathrm{Cr}(\mathrm{VI})$ may promote proteotoxic stress and, ultimately, activate the stress response through various mechanisms. For instance, changes in protein conformation may result from their direct interaction with $\mathrm{Cr}$ (III). Conformational changes may also be a consequence of oxidative stress, as it may originate incorrect disulfide bonds and other forms of protein modification [116]. The induction of mutations, as found in in vivo and in vitro systems [133], can also compromise the correct folding of the affected proteins [28].

The number of published studies on the impact of $\mathrm{Cr}(\mathrm{VI})$ on the stress response is still small. In addition, most of these studies did not specifically address the role of the stress response on carcinogenesis. Namely, some of the earlier studies were exploiting the then relatively recent array cDNA technology to simultaneously investigate multiple gene pathways that might be affected by $\mathrm{Cr}(\mathrm{VI})$ exposure $[48,56]$. Table 1 summarizes all the studies covered in this review.

The first observation of an effect of $\mathrm{Cr}(\mathrm{VI})$ on the stress response was made in 1998, on a molecular toxicology study aimed at developing a sensitive biological system for the rapid detection of low levels of environmental pollutants [49]. Using a radiolabeled antisense RNA probe, the authors found that, at mildly cytotoxic concentrations, a $6 \mathrm{~h}$ exposure to $\mathrm{Cr}(\mathrm{VI})$ increased Hsp72 mRNA levels, in HepG2 and HT29 cells. These results confirmed that HSP activation is exquisitely sensitive to $\mathrm{Cr}(\mathrm{VI})$ exposure, as changes in Hsp72 transcript levels could be detected for $\mathrm{Cr}(\mathrm{VI})$ concentrations as low as $0.5 \mu \mathrm{M}$. Of note, mRNA levels were determined $3 \mathrm{~h}$ after the stressing exposure, as it was observed that, after heat shock, transcript levels strongly increased in the first $3 \mathrm{~h}$, then decreasing to nearly basal levels $6 \mathrm{~h}$ after shock. In an independent study, protein levels peaked instead at $6 \mathrm{~h}$ after exposure [134], stressing the importance of conducting adequate time courses.

The second report of $\mathrm{Cr}(\mathrm{VI})$ impacting the stress response came from a study aimed at identifying metal-responsive promoters and, ultimately, new signal transduction pathways that might be modulated by exposure to this and other environmental pollutants [50]. To this end, 13 recombinant HepG2 cell lines, each of which stably transfected with a specific stress-responsive promoter regulating the 
expression of the chloramphenicol acetyl transferase (CAT) reporter gene, was exposed, for $48 \mathrm{~h}$, to different $\mathrm{Cr}(\mathrm{VI})$ concentrations. Intracellular levels of CAT protein were determined immediately after exposure. In the case of the two cell lines that had been transfected with HSP promoters, specifically the HSP70 and Grp78 gene promoters, a subcytotoxic $\mathrm{Cr}(\mathrm{VI})$ concentration induced CAT upregulation, even though statistical significance was only reached in the cell line transfected with the HSP70 promoter. At a higher $\mathrm{Cr}(\mathrm{VI})$ concentration, $\mathrm{CAT}$ protein levels were further augmented, yet this was accompanied by a dramatic decrease in cell viability. The results of this study highlighted the different susceptibilities of these two HSP to $\mathrm{Cr}(\mathrm{VI})$.

$\mathrm{Cr}(\mathrm{VI})$ is a lung carcinogen and, as such, studies conducted on human epithelial lung cells should be particularly informative. In the A549 cell line, established from a human lung adenocarcinoma, a $2 \mathrm{~h} \mathrm{Cr}(\mathrm{VI})$ exposure upregulated the transcript levels of TRAP1, the mitochondrial homologue of Hsp90 [56]. However, the $\mathrm{Cr}(\mathrm{VI})$ concentration used in this study was extremely high and would likely cause massive cell death for longer exposures. Therefore, the results of this study must be interpreted with caution. Nonetheless, it was recently reported, also in the A549 cell line, that a much lower $\mathrm{Cr}(\mathrm{VI})$ concentration upregulated Grp78 protein levels, again peaking at $6 \mathrm{~h}$ of $\mathrm{Cr}(\mathrm{VI})$ exposure [55]. The exquisite sensitivity of Grp78 to $\mathrm{Cr}(\mathrm{VI})$ is noteworthy. In L-02 hepatocytes, Grp78 mRNA levels were increased after a $24 \mathrm{~h}$ exposure to $\mathrm{Cr}(\mathrm{VI})$ in the low micromolar range [54]. In the same cell line, a similar exposure regimen, which was found to induce significant cytotoxicity, decreased the protein levels of both HSP70 and HSP90 [53].

Two studies have been conducted in the BEAS-2B cell line, established from normal human bronchial epithelium, which is the main target of $\mathrm{Cr}(\mathrm{VI})$ carcinogenicity. Both studies used $\mathrm{Cr}(\mathrm{VI})$ concentrations that did not cause overt cytotoxicity. The first study aimed at identifying specific and sensitive biomarkers of toxic metal exposure [46]. One significant finding was the extreme specificity of the $\mathrm{Cr}(\mathrm{VI})$ effects: of the 1200 gene transcripts analyzed, only 44 had their expression altered after a $4 \mathrm{~h} \mathrm{Cr}(\mathrm{VI})$ exposure. Of the 44 genes affected, 3 encoded HSP (HSP40, HSP60 and HSP90A) and were all down-regulated. The transcript levels of all other HSP analyzed (HSP27, HSP-70, HSP70.1, HSP-71) remained unchanged, giving further support to the perception that the impact of $\mathrm{Cr}(\mathrm{VI})$ is isoform-specific.

The second study employing BEAS-2B cells investigated the impact of $\mathrm{Cr}(\mathrm{VI})$ on the expression of the Hsp72 and Hsp90 $\alpha$ isoforms at both the transcript and protein levels [47]. Importantly, this study unveiled decoupling of mRNA and protein levels for both Hsp72 and Hsp90 $\alpha$. After a 48 h incubation with $\mathrm{Cr}(\mathrm{VI})$, Hsp72 mRNA levels were decreased, whereas Hsp72 protein levels remained unchanged. For Hsp90 $\alpha$, mRNA levels were unaltered, whereas protein levels were decreased. This decoupling is likely multifactorial, potentially involving critical post-transcriptional regulators, such as RNA binding proteins and microRNAs $[135,136]$. Protein stability and turnover may also have to be taken into account $[137,138]$. Thus, in future studies, it will be important to conduct detailed time-courses of the effects of $\mathrm{Cr}(\mathrm{VI})$ on gene expression at both levels.

There are another two cellular studies on the impact of $\mathrm{Cr}(\mathrm{VI})$ on HSP70 [51,52] and one on the impact of this carcinogen on HSP90 [52]. Altogether, these studies clearly show that this impact is dependent on both the cellular model employed and on the experimental design.

Another study, conducted in rat lung epithelial cells, showed the impact of $\mathrm{Cr}(\mathrm{VI})$ on additional HSP isoforms, namely Hsp10 and Hsp105, whose protein levels were increased after a $24 \mathrm{~h}$ incubation, which was shown to produce significant cytotoxicity [42]. Two other studies, one employing HaCaT [43] cells and the other employing human primary skin fibroblasts [44], unveiled $\mathrm{Cr}(\mathrm{VI})$ ability to alter the phosphorylation state of HSP27. Of note, aberrant phosphorylation of HSP27 has been associated with cancer [139]. In HaCaT cells, HSP27 expression was upregulated by $\mathrm{Cr}(\mathrm{VI})$ at both transcript and protein levels, but the phosphorylation of this HSP was decreased [43]. On the contrary, levels of phosphorylated HSP27 were found to be increased in $\mathrm{Cr}(\mathrm{VI})$-exposed in human primary skin fibroblasts [44]. This apparent contradiction might be explained by differences in cell model, $\mathrm{Cr}(\mathrm{VI})$ concentration and/or time of exposure. 
In the only two in vivo studies conducted to date, one employing ICR mice [45] and the other Sprague-Dawley rats [48], Cr(VI) administration induced HSP expression. In ICR mice, $\mathrm{Cr}(\mathrm{VI})$ intraperitoneal injection increased liver HSP27 and HSP70 protein levels. In Sprague-Dawley rats, $\mathrm{Cr}(\mathrm{VI})$ intratracheal instillation increased HSP70 mRNA levels in the lungs, whereas these levels were unaltered in the liver. HSP60, Grp75 and Grp94 mRNA levels, on the other hand, were unaffected in both lungs and liver. In fact, none of the 216 genes assessed had their liver mRNA levels altered, whereas changes in lung mRNA levels were observed for 52 genes. The observed lack of effects in the liver was ascribed to the upstream reduction and consequent detoxification of $\mathrm{Cr}(\mathrm{VI})$, firstly in the lung, then in the blood of the general circulation and finally in the liver itself.

\section{Concluding Remarks}

While the results obtained in the studies published thus far do not constitute a direct proof of a link between the stress response and $\mathrm{Cr}(\mathrm{VI})$-induced carcinogenesis, they do show the ability of this carcinogen to modulate the expression of several components of this response under conditions of biological relevance. It has also become clear that the observed effects are dependent on tissue, cell type, $\mathrm{Cr}(\mathrm{VI})$ concentration, time of exposure and HSP isoform. Thus, future studies must address the issue of biological relevance and should also include adequate time courses, as it has been shown that HSP transcript and protein levels changed over time during the recovery period. Only through rational and solid experimental designs will it be possible to make further advances in this field and unequivocally determine whether the stress response does play a role in $\mathrm{Cr}(\mathrm{VI})$-induced carcinogenesis.

Funding: The authors' original work on the impact of hexavalent chromium on HSP expression was funded by Centro de Investigação em Meio Ambiente, Genética e Oncobiologia (CIMAGO), Portugal (grant 16/12) and Fundação para a Ciência e a Tecnologia (FCT), Portugal (grants UID/Multi/00070/2019 and UID/NEU/04539/2019). The authors were also supported by the following FCT grants: PD/BD/128284/2017 (to PLA), SFRH/BD/91614/2012 (to LMRF), POCI-01-0145-FEDER-029297 (to TCO) and PTDC/MAR-BIO/6149/2014 (to MCA).

Acknowledgments: The authors apologize for any studies on the subject that were not mentioned in this review.

Conflicts of Interest: The authors declare no conflict of interest.

$\begin{array}{ll}\text { Abbreviations } \\ \text { ATF } & \text { Activating transcription factor associated with stress } \\ \text { CAT } & \text { Chloramphenicol acetyl transferase } \\ \text { Cr } & \text { Chromium } \\ \text { Cr(III) } & \text { Chromium in the trivalent oxidation state } \\ \text { Cr(IV) } & \text { Chromium in the tetravalent oxidation state } \\ \text { Cr(V) } & \text { Chromium in the pentavalent oxidation state } \\ \text { Cr(VI) } & \text { Chromium in the hexavalent oxidation state } \\ \text { DSB } & \text { Double-strand break } \\ \text { ER } & \text { Endoplasmic reticulum } \\ \text { HSF1 } & \text { Heat shock factor 1 } \\ \text { Hsp } & \text { Heat shock protein (see Section 3.1) } \\ \text { HSP } & \text { Heat shock proteins (see Section 3.1) } \\ \text { MAM } & \text { Mitochondria-associated membrane } \\ \text { ROS } & \text { Reactive oxygen species } \\ \text { SSB } & \text { Single-strand break } \\ \text { TRAP1 } & \text { Tumor necrosis factor receptor-associated protein 1 } \\ \text { UPR } & \text { Unfolded protein response } \\ \text { UPRmt } & \text { Mitochondrial unfolded protein response }\end{array}$




\section{References}

1. Cotton, F.A. Advanced Inorganic Chemistry, 6th ed.; Wiley: New York, NY, USA, 1999; p. 1355.

2. Urbano, A.M.; Ferreira, L.M.R.; Alpoim, M.C. Molecular and cellular mechanisms of hexavalent chromium-induced lung cancer: An updated perspective. Curr. Drug Metab. 2012, 13, 284-305. [CrossRef] [PubMed]

3. Urbano, A.M.; Rodrigues, C.F.D.; Alpoim, M.C. Hexavalent chromium exposure, genomic instability and lung cancer. Gene Mol. Biol. 2008, 12B, 219-238.

4. Anderson, R.A. Chromium as an essential nutrient for humans. Regul. Toxicol. Pharm. 1997, 26, S35-S41. [CrossRef] [PubMed]

5. Jeejeebhoy, K.N. The role of chromium in nutrition and therapeutics and as a potential toxin. Nutr. Rev. 1999, 57, 329-335. [CrossRef] [PubMed]

6. EFSA. Scientific opinion on dietary reference values for chromium. Efsa J. 2014, 12, 25. [CrossRef]

7. IARC. Chromium, nickel and welding. Iarc Monogr. Eval. Carcinog. Risks Hum. 1990, 49, 1-648.

8. IARC. Arsenic, metals, fibres and dusts. Iarc Monogr. Eval. Carcinog. Risks Hum. 2012, 100, 1-465.

9. NTP. Report on Carcinogens, 13th ed.; Research Triangle Park, NC, USA, 2015.

10. Alexander, J.; Aaseth, J. Uptake of chromate in human red-blood-cells and isolated rat-liver cells-The role of the anion carrier. Analyst 1995, 120, 931-933. [CrossRef] [PubMed]

11. O’Brien, T.J.; Ceryak, S.; Patierno, S.R. Complexities of chromium carcinogenesis: Role of cellular response, repair and recovery mechanisms. Mutat. Res. 2003, 533, 3-36. [CrossRef]

12. Biedermann, K.A.; Landolph, J.R. Role of valence state and solubility of chromium compounds on induction of cytotoxicity, mutagenesis, and anchorage independence in diploid human fibroblasts. Cancer Res. 1990, 50, 7835-7842.

13. Ishikawa, Y.; Nakagawa, K.; Satoh, Y.; Kitagawa, T.; Sugano, H.; Hirano, T.; Tsuchiya, E. Hot spots of chromium accumulation at bifurcations of chromate workers bronchi. Cancer Res. 1994, 54, 2342-2346. [PubMed]

14. Yatera, K.; Morimoto, Y.; Ueno, S.; Noguchi, S.; Kawaguchi, T.; Tanaka, F.; Suzuki, H.; Higashi, T. Cancer risks of hexavalent chromium in the respiratory tract. J. Uoeh 2018, 40, 157-172. [CrossRef] [PubMed]

15. Kondo, K.; Takahashi, Y.; Ishikawa, S.; Uchihara, H.; Hirose, Y.; Yoshizawa, K.; Tsuyuguchi, M.; Takizawa, H.; Miyoshi, T.; Sakiyama, S.; et al. Microscopic analysis of chromium accumulation in the bronchi and lung of chromate workers. Cancer 2003, 98, 2420-2429. [CrossRef] [PubMed]

16. Ishikawa, Y.; Nakagawa, K.; Satoh, Y.; Kitagawa, T.; Sugano, H.; Hirano, T.; Tsuchiya, E. Characteristics of chromate workers cancers, chromium lung deposition and precancerous bronchial lesions-An autopsy study. Br. J. Cancer 1994, 70, 160-166. [CrossRef] [PubMed]

17. Barceloux, D.G. Chromium. J. Toxicol. Clin. Toxicol. 1999, 37, 173-194. [CrossRef] [PubMed]

18. Fearon, E.R.; Vogelstein, B. A genetic model for colorectal tumorigenesis. Cell 1990, 61, 759-767. [CrossRef]

19. Olive, K.P.; Tuveson, D.A.; Ruhe, Z.C.; Yin, B.; Willis, N.A.; Bronson, R.T.; Crowley, D.; Jacks, T. Mutant p53 gain of function in two mouse models of Li-Fraumeni syndrome. Cell 2004, 119, 847-860. [CrossRef]

20. Cancer Genome Atlas Research Network; Weinstein, J.N.; Collisson, E.A.; Mills, G.B.; Shaw, K.R.; Ozenberger, B.A.; Ellrott, K.; Shmulevich, I.; Sander, C.; Stuart, J.M. The Cancer Genome Atlas Pan-Cancer analysis project. Nat. Genet. 2013, 45, 1113-1120. [CrossRef]

21. Pitot, H.C. The molecular biology of carcinogenesis. Cancer 1993, 72, 962-970. [CrossRef]

22. Ferreira, L.M. Cancer metabolism: The Warburg effect today. Exp. Mol. Pathol. 2010, 89, 372-380. [CrossRef]

23. Abreu, P.L.; Urbano, A.M. Targeting the Warburg effect for cancer therapy: A long and winding road. Front. Clin. Drug Res.-Anti-Cancer Agents 2016, 3, 271-324.

24. Acharya, A.; Das, I.; Chandhok, D.; Saha, T. Redox regulation in cancer: A double-edged sword with therapeutic potential. Oxid. Med. Cell Longev. 2010, 3, 23-34. [CrossRef] [PubMed]

25. Schar, P. Spontaneous DNA damage, genome instability, and cancer-When DNA replication escapes control. Cell 2001, 104, 329-332. [CrossRef]

26. Galadari, S.; Rahman, A.; Pallichankandy, S.; Thayyullathil, F. Reactive oxygen species and cancer paradox: To promote or to suppress? Free Radic Biol. Med. 2017, 104, 144-164. [CrossRef]

27. Hanahan, D.; Weinberg, R.A. Hallmarks of cancer: The next generation. Cell 2011, 144, 646-674. [CrossRef] [PubMed] 
28. Hartl, F.U.; Hayer-Hartl, M. Converging concepts of protein folding in vitro and in vivo. Nat. Struct. Mol. Biol. 2009, 16, 574-581. [CrossRef] [PubMed]

29. Vandewynckel, Y.P.; Laukens, D.; Geerts, A.; Bogaerts, E.; Paridaens, A.; Verhelst, X.; Janssens, S.; Heindryckx, F.; Van Vlierberghe, H. The paradox of the unfolded protein response in cancer. Anticancer Res. 2013, 33, 4683-4694.

30. Bussard, K.M.; Mutkus, L.; Stumpf, K.; Gomez-Manzano, C.; Marini, F.C. Tumor-associated stromal cells as key contributors to the tumor microenvironment. Breast Cancer Res. 2016, 18, 84. [CrossRef]

31. Thommen, D.S.; Schumacher, T.N. T cell dysfunction in cancer. Cancer Cell 2018, 33, 547-562. [CrossRef]

32. Kerbel, R.S. Tumor angiogenesis. N. Engl. J. Med. 2008, 358, 2039-2049. [CrossRef]

33. Pflaum, J.; Schlosser, S.; Muller, M. p53 family and cellular stress responses in cancer. Front. Oncol. 2014, 4, 285. [CrossRef] [PubMed]

34. Herr, I.; Debatin, K.M. Cellular stress response and apoptosis in cancer therapy. Blood 2001, 98, $2603-2614$. [CrossRef] [PubMed]

35. Neri, D.; Supuran, C.T. Interfering with $\mathrm{pH}$ regulation in tumours as a therapeutic strategy. Nat. Rev. Drug Discov. 2011, 10, 767-777. [CrossRef] [PubMed]

36. Bertout, J.A.; Patel, S.A.; Simon, M.C. The impact of $\mathrm{O}_{2}$ availability on human cancer. Nat. Rev. Cancer 2008, 8, 967-975. [CrossRef] [PubMed]

37. Bolhaqueiro, A.C.F.; Ponsioen, B.; Bakker, B.; Klaasen, S.J.; Kucukkose, E.; van Jaarsveld, R.H.; Vivie, J.; Verlaan-Klink, I.; Hami, N.; Spierings, D.C.J.; et al. Ongoing chromosomal instability and karyotype evolution in human colorectal cancer organoids. Nat. Genet. 2019, 51, 824-834. [CrossRef] [PubMed]

38. Kost, G.C.; Patierno, S.R.; Wise, S.S.; Holmes, A.L.; Wise, J.P., Sr.; Ceryak, S. Protein tyrosine phosphatase (PTP) inhibition enhances chromosomal stability after genotoxic stress: Decreased chromosomal instability (CIN) at the expense of enhanced genomic instability (GIN)? Mutat. Res. 2012, 735, 51-55. [CrossRef] [PubMed]

39. Velegzhaninov, I.O.; Ievlev, V.A.; Pylina, Y.I.; Shadrin, D.M.; Vakhrusheva, O.M. Programming of cell resistance to genotoxic and oxidative stress. Biomedicines 2018, 6. [CrossRef]

40. Schlesinger, M.J. Heat shock proteins. J. Biol. Chem. 1990, 265, 12111-12114.

41. Kampinga, H.H.; Hageman, J.; Vos, M.J.; Kubota, H.; Tanguay, R.M.; Bruford, E.A.; Cheetham, M.E.; Chen, B.; Hightower, L.E. Guidelines for the nomenclature of the human heat shock proteins. Cell Stress Chaperones 2009, 14, 105-111. [CrossRef]

42. Lei, T.; He, Q.Y.; Cai, Z.; Zhou, Y.; Wang, Y.L.; Si, L.S.; Chiu, J.F. Proteomic analysis of chromium cytotoxicity in cultured rat lung epithelial cells. Proteomics 2008, 8, 2420-2429. [CrossRef]

43. Zhang, Q.; Zhang, L.; Xiao, X.; Su, Z.; Zou, P.; Hu, H.; Huang, Y.; He, Q.Y. Heavy metals chromium and neodymium reduced phosphorylation level of heat shock protein 27 in human keratinocytes. Toxicol. Vitr. 2010, 24, 1098-1104. [CrossRef] [PubMed]

44. Rudolf, E.; Cervinka, M. Nickel modifies the cytotoxicity of hexavalent chromium in human dermal fibroblasts. Toxicol. Lett. 2010, 197, 143-150. [CrossRef] [PubMed]

45. Lee, J.; Lim, K.T. Inhibitory effect of SJSZ glycoprotein ( $38 \mathrm{kDa})$ on expression of heat shock protein 27 and 70 in chromium (VI)-treated hepatocytes. Mol. Cell Biochem. 2012, 359, 45-57. [CrossRef] [PubMed]

46. Andrew, A.S.; Warren, A.J.; Barchowsky, A.; Temple, K.A.; Klei, L.; Soucy, N.V.; O’Hara, K.A.; Hamilton, J.W. Genomic and proteomic profiling of responses to toxic metals in human lung cells. Environ. Health Perspect. 2003, 111, 825-835. [CrossRef] [PubMed]

47. Abreu, P.L.; Cunha-Oliveira, T.; Ferreira, L.M.R.; Urbano, A.M. Hexavalent chromium, a lung carcinogen, confers resistance to thermal stress and interferes with heat shock protein expression in human bronchial epithelial cells. Biometals 2018, 31, 477-487. [CrossRef] [PubMed]

48. Izzotti, A.; Cartiglia, C.; Balansky, R.; D'Agostini, F.; Longobardi, M.; De Flora, S. Selective induction of gene expression in rat lung by hexavalent chromium. Mol. Carcinog. 2002, 35, 75-84. [CrossRef] [PubMed]

49. Delmas, F.; Schaak, S.; Gaubin, Y.; Croute, F.; Arrabit, C.; Murat, J.C. Hsp72 mRNA production in cultured human cells submitted to nonlethal aggression by heat, ethanol, or propanol. Application to the detection of low concentrations of chromium(VI) (potassium dichromate). Cell Biol. Toxicol. 1998, 14, 39-46. [CrossRef] [PubMed] 
50. Tully, D.B.; Collins, B.J.; Overstreet, J.D.; Smith, C.S.; Dinse, G.E.; Mumtaz, M.M.; Chapin, R.E. Effects of arsenic, cadmium, chromium, and lead on gene expression regulated by a battery of 13 different promoters in recombinant HepG2 cells. Toxicol. Appl. Pharm. 2000, 168, 79-90. [CrossRef] [PubMed]

51. Majumder, S.; Ghoshal, K.; Summers, D.; Bai, S.; Datta, J.; Jacob, S.T. Chromium(VI) down-regulates heavy metal-induced metallothionein gene transcription by modifying transactivation potential of the key transcription factor, metal-responsive transcription factor 1. J. Biol. Chem. 2003, 278, 26216-26226. [CrossRef]

52. Banu, S.K.; Stanley, J.A.; Lee, J.; Stephen, S.D.; Arosh, J.A.; Hoyer, P.B.; Burghardt, R.C. Hexavalent chromium-induced apoptosis of granulosa cells involves selective sub-cellular translocation of Bcl-2 members, ERK1/2 and p53. Toxicol. Appl. Pharm. 2011, 251, 253-266. [CrossRef] [PubMed]

53. Xiao, F.; Li, Y.; Dai, L.; Deng, Y.; Zou, Y.; Li, P.; Yang, Y.; Zhong, C. Hexavalent chromium targets mitochondrial respiratory chain complex I to induce reactive oxygen species-dependent caspase-3 activation in L-02 hepatocytes. Int. J. Mol. Med. 2012, 30, 629-635. [CrossRef] [PubMed]

54. Liang, Q.; Zhang, Y.; Huang, M.; Xiao, Y.; Xiao, F. Role of mitochondrial damage in Cr(VI)induced endoplasmic reticulum stress in L02 hepatocytes. Mol. Med. Rep. 2019, 19, 1256-1265. [CrossRef] [PubMed]

55. Ge, H.; Li, Z.; Jiang, L.; Li, Q.; Geng, C.; Yao, X.; Shi, X.; Liu, Y.; Cao, J. Cr (VI) induces crosstalk between apoptosis and autophagy through endoplasmic reticulum stress in A549 cells. Chem. Biol. Interact. 2019, 298, 35-42. [CrossRef] [PubMed]

56. Ye, J.P.; Shi, X.L. Gene expression profile in response to chromium-induced cell stress in A549 cells. Mol. Cell Biochem. 2001, 222, 189-197. [CrossRef] [PubMed]

57. Csermely, P.; Schnaider, T.; Soti, C.; Prohaszka, Z.; Nardai, G. The 90-kDa molecular chaperone family: Structure, function, and clinical applications. A comprehensive review. Pharmacol. Ther. 1998, 79, 129-168. [CrossRef]

58. Makhnevych, T.; Houry, W.A. The role of Hsp90 in protein complex assembly. Biochim. Biophys. Acta 2012, 1823, 674-682. [CrossRef] [PubMed]

59. Lindquist, S. The heat-shock response. Annu. Rev. Biochem. 1986, 55, 1151-1191. [CrossRef]

60. Vihervaara, A.; Sistonen, L. HSF1 at a glance. J. Cell Sci. 2014, 127, 261-266. [CrossRef]

61. Morimoto, R.I. Regulation of the heat shock transcriptional response: Cross talk between a family of heat shock factors, molecular chaperones, and negative regulators. Genes Dev. 1998, 12, 3788-3796. [CrossRef]

62. Schwarz, D.S.; Blower, M.D. The endoplasmic reticulum: Structure, function and response to cellular signaling. Cell Mol. Life Sci. 2016, 73, 79-94. [CrossRef]

63. Diaz-Villanueva, J.F.; Diaz-Molina, R.; Garcia-Gonzalez, V. Protein folding and mechanisms of proteostasis. Int. J. Mol. Sci. 2015, 16, 17193-17230. [CrossRef] [PubMed]

64. Hetz, C.; Chevet, E.; Oakes, S.A. Proteostasis control by the unfolded protein response. Nat. Cell Biol. 2015, 17, 829-838. [CrossRef] [PubMed]

65. Gardner, B.M.; Pincus, D.; Gotthardt, K.; Gallagher, C.M.; Walter, P. Endoplasmic reticulum stress sensing in the unfolded protein response. Cold Spring Harb. Perspect. Biol. 2013, 5, a013169. [CrossRef] [PubMed]

66. Cubillos-Ruiz, J.R.; Bettigole, S.E.; Glimcher, L.H. Tumorigenic and immunosuppressive effects of endoplasmic reticulum stress in cancer. Cell 2017, 168, 692-706. [CrossRef] [PubMed]

67. Obeng, E.A.; Carlson, L.M.; Gutman, D.M.; Harrington, W.J., Jr.; Lee, K.P.; Boise, L.H. Proteasome inhibitors induce a terminal unfolded protein response in multiple myeloma cells. Blood 2006, 107, 4907-4916. [CrossRef] [PubMed]

68. Ni, M.; Lee, A.S. ER chaperones in mammalian development and human diseases. Febs Lett. 2007, 581, 3641-3651. [CrossRef]

69. Galluzzi, L.; Yamazaki, T.; Kroemer, G. Linking cellular stress responses to systemic homeostasis. Nat. Rev. Mol. Cell Biol. 2018, 19, 731-745. [CrossRef]

70. Fulda, S.; Gorman, A.M.; Hori, O.; Samali, A. Cellular stress responses: Cell survival and cell death. Int. J. Cell Biol. 2010, 2010, 214074. [CrossRef]

71. Tsai, Y.C.; Weissman, A.M. The Unfolded Protein Response, degradation from endoplasmic reticulum and cancer. Genes Cancer 2010, 1, 764-778. [CrossRef]

72. Carreras-Sureda, A.; Pihan, P.; Hetz, C. The Unfolded Protein Response: At the intersection between endoplasmic reticulum function and mitochondrial bioenergetics. Front. Oncol 2017, 7, 55. [CrossRef]

73. Rieusset, J. The role of endoplasmic reticulum-mitochondria contact sites in the control of glucose homeostasis: An update. Cell Death Dis. 2018, 9, 388. [CrossRef] [PubMed] 
74. Altieri, D.C.; Stein, G.S.; Lian, J.B.; Languino, L.R. TRAP-1, the mitochondrial Hsp90. Biochim. Biophys. Acta 2012, 1823, 767-773. [CrossRef] [PubMed]

75. Takemoto, K.; Miyata, S.; Takamura, H.; Katayama, T.; Tohyama, M. Mitochondrial TRAP1 regulates the unfolded protein response in the endoplasmic reticulum. Neurochem. Int. 2011, 58, 880-887. [CrossRef] [PubMed]

76. Li, J.; Lee, B.; Lee, A.S. Endoplasmic reticulum stress-induced apoptosis: Multiple pathways and activation of p53-up-regulated modulator of apoptosis (PUMA) and NOXA by p53. J. Biol. Chem. 2006, 281, 7260-7270. [CrossRef] [PubMed]

77. Hori, O.; Ichinoda, F.; Tamatani, T.; Yamaguchi, A.; Sato, N.; Ozawa, K.; Kitao, Y.; Miyazaki, M.; Harding, H.P.; Ron, D.; et al. Transmission of cell stress from endoplasmic reticulum to mitochondria: Enhanced expression of Lon protease. J. Cell Biol. 2002, 157, 1151-1160. [CrossRef] [PubMed]

78. Pinti, M.; Gibellini, L.; Nasi, M.; De Biasi, S.; Bortolotti, C.A.; Iannone, A.; Cossarizza, A. Emerging role of Lon protease as a master regulator of mitochondrial functions. Biochim. Biophys. Acta 2016, 1857, 1300-1306. [CrossRef] [PubMed]

79. Schneider, K.; Bertolotti, A. Surviving protein quality control catastrophes - from cells to organisms. J. Cell Sci. 2015, 128, 3861-3869. [CrossRef]

80. Lin, Y.F.; Haynes, C.M. Metabolism and the UPR(mt). Mol. Cell 2016, 61, 677-682. [CrossRef]

81. Melber, A.; Haynes, C.M. UPR(mt) regulation and output: A stress response mediated by mitochondrial-nuclear communication. Cell Res. 2018, 28, 281-295. [CrossRef]

82. Fiorese, C.J.; Haynes, C.M. Integrating the UPR(mt) into the mitochondrial maintenance network. Crit. Rev. Biochem. Mol. Biol. 2017, 52, 304-313. [CrossRef]

83. Fiorese, C.J.; Schulz, A.M.; Lin, Y.F.; Rosin, N.; Pellegrino, M.W.; Haynes, C.M. The transcription factor ATF5 mediates a mammalian mitochondrial UPR. Curr. Biol. 2016, 26, 2037-2043. [CrossRef] [PubMed]

84. Xia, M.; Zhang, Y.; Jin, K.; Lu, Z.; Zeng, Z.; Xiong, W. Communication between mitochondria and other organelles: A brand-new perspective on mitochondria in cancer. Cell Biosci. 2019, 9, 27. [CrossRef] [PubMed]

85. Hsu, C.C.; Tseng, L.M.; Lee, H.C. Role of mitochondrial dysfunction in cancer progression. Exp. Biol. Med. (Maywood) 2016, 241, 1281-1295. [CrossRef] [PubMed]

86. Ciocca, D.R.; Arrigo, A.P.; Calderwood, S.K. Heat shock proteins and heat shock factor 1 in carcinogenesis and tumor development: An update. Arch. Toxicol. 2013, 87, 19-48. [CrossRef]

87. Whitesell, L.; Lindquist, S. Inhibiting the transcription factor HSF1 as an anticancer strategy. Expert Opin. Targets 2009, 13, 469-478. [CrossRef]

88. Dai, C.; Whitesell, L.; Rogers, A.B.; Lindquist, S. Heat shock factor 1 is a powerful multifaceted modifier of carcinogenesis. Cell 2007, 130, 1005-1018. [CrossRef]

89. Saretzki, G.; Armstrong, L.; Leake, A.; Lako, M.; von Zglinicki, T. Stress defense in murine embryonic stem cells is superior to that of various differentiated murine cells. Stem Cells 2004, 22, 962-971. [CrossRef]

90. Oesterreich, S.; Weng, C.N.; Qiu, M.; Hilsenbeck, S.G.; Osborne, C.K.; Fuqua, S.A. The small heat shock protein hsp27 is correlated with growth and drug resistance in human breast cancer cell lines. Cancer Res. 1993, 53, 4443-4448.

91. Nahleh, Z.; Tfayli, A.; Najm, A.; El Sayed, A.; Nahle, Z. Heat shock proteins in cancer: Targeting the 'chaperones'. Future Med. Chem. 2012, 4, 927-935. [CrossRef]

92. Whitesell, L.; Lindquist, S.L. HSP90 and the chaperoning of cancer. Nat. Rev. Cancer 2005, 5, 761-772. [CrossRef]

93. Trepel, J.; Mollapour, M.; Giaccone, G.; Neckers, L. Targeting the dynamic HSP90 complex in cancer. Nat. Rev. Cancer 2010, 10, 537-549. [CrossRef] [PubMed]

94. Barrott, J.J.; Haystead, T.A. Hsp90, an unlikely ally in the war on cancer. Febs J. 2013, 280, 1381-1396. [CrossRef] [PubMed]

95. Abreu, P.L.; Ferreira, L.M.R.; Cunha-Oliveira, T.; Alpoim, M.C.; Urbano, A.M. HSP90: A key player in metal-induced carcinogenesis? In Heat Shock Protein 90 in Human Diseases and Disorders; Asea, A.A., Kaur, P., Eds.; Springer International Publishing: New York, NY, USA, 2019.

96. Ziemiecki, A.; Catelli, M.G.; Joab, I.; Moncharmont, B. Association of the heat shock protein hsp90 with steroid hormone receptors and tyrosine kinase oncogene products. Biochem. Biophys. Res. Commun. 1986, 138, 1298-1307. [CrossRef] 
97. Holt, S.E.; Aisner, D.L.; Baur, J.; Tesmer, V.M.; Dy, M.; Ouellette, M.; Trager, J.B.; Morin, G.B.; Toft, D.O.; Shay, J.W.; et al. Functional requirement of p23 and Hsp90 in telomerase complexes. Genes Dev. 1999, 13, 817-826. [CrossRef]

98. Basso, A.D.; Solit, D.B.; Chiosis, G.; Giri, B.; Tsichlis, P.; Rosen, N. Akt forms an intracellular complex with heat shock protein 90 (Hsp90) and Cdc37 and is destabilized by inhibitors of Hsp90 function. J. Biol. Chem. 2002, 277, 39858-39866. [CrossRef]

99. Isaacs, J.S.; Jung, Y.J.; Mimnaugh, E.G.; Martinez, A.; Cuttitta, F.; Neckers, L.M. Hsp90 regulates a von Hippel Lindau-independent hypoxia-inducible factor-1 alpha-degradative pathway. J. Biol. Chem. 2002, 277, 29936-29944. [CrossRef] [PubMed]

100. Ferreira, L.M.; Hebrant, A.; Dumont, J.E. Metabolic reprogramming of the tumor. Oncogene 2012, 31, 3999-4011. [CrossRef]

101. Eustace, B.K.; Sakurai, T.; Stewart, J.K.; Yimlamai, D.; Unger, C.; Zehetmeier, C.; Lain, B.; Torella, C.; Henning, S.W.; Beste, G.; et al. Functional proteomic screens reveal an essential extracellular role for hsp90 alpha in cancer cell invasiveness. Nat. Cell Biol. 2004, 6, 507-514. [CrossRef]

102. Pockley, A.G.; Multhoff, G. Cell stress proteins in extracellular fluids: Friend or foe? Novartis Found. Symp. 2008, 291, 86-95.

103. Sidera, K.; Patsavoudi, E. HSP90 inhibitors: Current development and potential in cancer therapy. Recent Pat. Anticancer Drug Discov. 2014, 9, 1-20. [CrossRef]

104. Arakawa, H.; Weng, M.W.; Chen, W.C.; Tang, M.S. Chromium (VI) induces both bulky DNA adducts and oxidative DNA damage at adenines and guanines in the p53 gene of human lung cells. Carcinogenesis 2012, 33, 1993-2000. [CrossRef] [PubMed]

105. Wise, S.S.; Holmes, A.L.; Qin, Q.; Xie, H.; Katsifis, S.P.; Thompson, W.D.; Wise, J.P. Comparative genotoxicity and cytotoxicity of four hexavalent chromium compounds in human bronchial cells. Chem. Res. Toxicol. 2010, 23, 365-372. [CrossRef] [PubMed]

106. Thompson, C.M.; Fedorov, Y.; Brown, D.D.; Suh, M.; Proctor, D.M.; Kuriakose, L.; Haws, L.C.; Harris, M.A. Assessment of $\mathrm{Cr}(\mathrm{VI})$-induced cytotoxicity and genotoxicity using high content analysis. PLoS ONE 2012, 7. [CrossRef] [PubMed]

107. Reynolds, M.; Armknecht, S.; Johnston, T.; Zhitkovich, A. Undetectable role of oxidative DNA damage in cell cycle, cytotoxic and clastogenic effects of $\mathrm{Cr}(\mathrm{VI})$ in human lung cells with restored ascorbate levels. Mutagenesis 2012, 27, 437-443. [CrossRef] [PubMed]

108. Izzotti, A.; Bagnasco, M.; Camoirano, A.; Orlando, M.; De Flora, S. DNA fragmentation, DNA-protein crosslinks, P-32 postlabeled nucleotidic modifications, and 8-hydroxy-2'-deoxyguanosine in the lung but not in the liver of rats receiving intratracheal instillations of chromium(VI). Chemoprevention by oral N-acetylcysteine. Mutat. Res. 1998, 400, 233-244. [CrossRef]

109. Figgitt, M.; Newson, R.; Leslie, I.J.; Fisher, J.; Ingham, E.; Case, C.P. The genotoxicity of physiological concentrations of chromium $(\mathrm{Cr}(\mathrm{III})$ and $\mathrm{Cr}(\mathrm{VI}))$ and cobalt $(\mathrm{Co}(\mathrm{II}))$ : An in vitro study. Mutat. Res. 2010, 688, 53-61. [CrossRef]

110. Reynolds, M.; Zhitkovich, A. Cellular vitamin C increases chromate toxicity via a death program requiring mismatch repair but not p53. Carcinogenesis 2007, 28, 1613-1620. [CrossRef] [PubMed]

111. Wetterhahn, K.E.; Hamilton, J.W.; Aiyar, J.; Borges, K.M.; Floyd, R. Mechanisms of Chromium(VI) carcinogenesis-Reactive intermediates and effect on gene-expression. Biol. Trace Elem. Res. 1989, 21, 405-411. [CrossRef]

112. Standeven, A.M.; Wetterhahn, K.E. Ascorbate is the principal reductant of chromium(VI) in rat lung ultrafiltrates and cytosols, and mediates chromium-DNA-binding invitro. Carcinogenesis 1992, 13, 1319-1324. [CrossRef]

113. Husain, N.; Mahmood, R. Hexavalent chromium induces reactive oxygen species and impairs the antioxidant power of human erythrocytes and lymphocytes: Decreased metal reducing and free radical quenching ability of the cells. Toxicol. Ind. Health 2017, 33, 623-635. [CrossRef]

114. Wang, B.J.; Sheu, H.M.; Guo, Y.L.; Lee, Y.H.; Lai, C.S.; Pan, M.H.; Wang, Y.J. Hexavalent chromium induced ROS formation, Akt, NF-kappaB, and MAPK activation, and TNF-alpha and IL-1alpha production in keratinocytes. Toxicol. Lett. 2010, 198, 216-224. [CrossRef] [PubMed]

115. Nickens, K.P.; Patierno, S.R.; Ceryak, S. Chromium genotoxicity: A double-edged sword. Chem. Biol. Interact. 2010, 188, 276-288. [CrossRef] [PubMed] 
116. Abreu, P.L.; Ferreira, L.M.R.; Alpoim, M.C.; Urbano, A.M. Impact of hexavalent chromium on mammalian cell bioenergetics: Phenotypic changes, molecular basis and potential relevance to chromate-induced lung cancer. Biometals 2014, 27, 409-443. [CrossRef] [PubMed]

117. Dubrovskaya, V.A.; Wetterhahn, K.E. Effects of $\mathrm{Cr}(\mathrm{VI})$ on the expression of the oxidative stress genes in human lung cells. Carcinogenesis 1998, 19, 1401-1407. [CrossRef] [PubMed]

118. Ye, J.P.; Zhang, X.Y.; Young, H.A.; Mao, Y.; Shi, X.L. Chromium(VI)-induced nuclear factor-kappa-B activation in intact-cells via free-radical reactions. Carcinogenesis 1995, 16, 2401-2405. [CrossRef] [PubMed]

119. Dalton, T.P.; Shertzer, H.G.; Puga, A. Regulation of gene expression by reactive oxygen. Annu. Rev. Pharm. Toxicol. 1999, 39, 67-101. [CrossRef]

120. Brooks, B.; O’Brien, T.J.; Ceryak, S.; Wise, J.P.; Wise, S.S.; Wise, J.P.; DeFabo, E.; Patierno, S.R. Excision repair is required for genotoxin-induced mutagenesis in mammalian cells. Carcinogenesis 2008, 29, 1064-1069. [CrossRef]

121. Robertson, A.B.; Klungland, A.; Rognes, T.; Leiros, I. DNA repair in mammalian cells. Cell Mol. Life Sci. 2009, 66, 981-993. [CrossRef]

122. O'Brien, T.J.; Brooks, B.R.; Patierno, S.R. Nucleotide excision repair functions in the removal of chromium-induced DNA damage in mammalian cells. Mol. Cell Biochem. 2005, 279, 85-95. [CrossRef]

123. Xie, H.; Wise, S.S.; Holmes, A.L.; Xu, B.; Wakeman, T.P.; Pelsue, S.C.; Singh, N.P.; Wise, J.P., Sr. Carcinogenic lead chromate induces DNA double-strand breaks in human lung cells. Mutat. Res. 2005, 586, 160-172. [CrossRef]

124. Hirose, T.; Kondo, K.; Takahashi, Y.; Ishikura, H.; Fujino, H.; Tsuyuguchi, M.; Hashimoto, M.; Yokose, T.; Mukai, K.; Kodama, T.; et al. Frequent microsatellite instability in lung cancer from chromate-exposed workers. Mol. Carcinog. 2002, 33, 172-180. [CrossRef] [PubMed]

125. Takahashi, Y.; Kondo, K.; Hirose, T.; Nakagawa, H.; Tsuyuguchi, M.; Hashimoto, M.; Sano, T.; Ochiai, A.; Monden, Y. Microsatellite instability and protein expression of the DNA mismatch repair gene, hMLH1, of lung cancer in chromate-exposed workers. Mol. Carcinog. 2005, 42, 150-158. [CrossRef] [PubMed]

126. Rodrigues, C.F.; Urbano, A.M.; Matoso, E.; Carreira, I.; Almeida, A.; Santos, P.; Botelho, F.; Carvalho, L.; Alves, M.; Monteiro, C.; et al. Human bronchial epithelial cells malignantly transformed by hexavalent chromium exhibit an aneuploid phenotype but no microsatellite instability. Mutat. Res. 2009, 670, 42-52. [CrossRef] [PubMed]

127. Arakawa, H.; Wu, F.; Costa, M.; Rom, W.; Tang, M.S. Sequence specificity of Cr(III)-DNA adduct formation in the p53 gene: NGG sequences are preferential adduct-forming sites. Carcinogenesis 2006, 27, 639-645. [CrossRef] [PubMed]

128. Daniels, C.E.; Jett, J.R. Does interstitial lung disease predispose to lung cancer? Curr. Opin. Pulm. Med. 2005, 11, 431-437. [CrossRef] [PubMed]

129. McKeown, D.J.; Brown, D.J.; Kelly, A.; Wallace, A.M.; McMillan, D.C. The relationship between circulating concentrations of $\mathrm{C}$-reactive protein, inflammatory cytokines and cytokine receptors in patients with non-small-cell lung cancer. Br. J. Cancer 2004, 91, 1993-1995. [CrossRef]

130. Beaver, L.M.; Stemmy, E.J.; Constant, S.L.; Schwartz, A.; Little, L.G.; Gigley, J.P.; Chun, G.; Sugden, K.D.; Ceryak, S.M.; Patierno, S.R. Lung injury, inflammation and Akt signaling following inhalation of particulate hexavalent chromium. Toxicol. Appl. Pharm. 2009, 235, 47-56. [CrossRef]

131. Beaver, L.M.; Stemmy, E.J.; Schwartz, A.M.; Damsker, J.M.; Constant, S.L.; Ceryak, S.M.; Patierno, S.R. Lung inflammation, injury, and proliferative response after repetitive particulate hexavalent chromium exposure. Environ. Health Perspect. 2009, 117, 1896-1902. [CrossRef]

132. Rodrigues, C.F.D.; Serrano, E.; Patricio, M.I.; Val, M.M.; Albuquerque, P.; Fonseca, J.; Gomes, C.M.F.; Abrunhosa, A.J.; Paiva, A.; Carvalho, L.; et al. Stroma-derived IL-6, G-CSF and Activin-A mediated dedifferentiation of lung carcinoma cells into cancer stem cells. Sci. Rep. 2018, 8, 11573. [CrossRef]

133. Holmes, A.L.; Wise, S.S.; Wise, J.P., Sr. Carcinogenicity of hexavalent chromium. Indian J. Med. Res. 2008, 128, 353-372.

134. Delmas, F.; Trocheris, V.; Murat, J.C. Expression of stress proteins in cultured HT29 human cell-line: A model for studying environmental aggression. Int. J. Biochem. Cell Biol. 1995, 27, 385-391. [CrossRef]

135. Glisovic, T.; Bachorik, J.L.; Yong, J.; Dreyfuss, G. RNA-binding proteins and post-transcriptional gene regulation. Febs Lett. 2008, 582, 1977-1986. [CrossRef] [PubMed] 
136. Janga, S.C.; Vallabhaneni, S. MicroRNAs as post-transcriptional machines and their interplay with cellular networks. Adv. Exp. Med. Biol. 2011, 722, 59-74. [CrossRef] [PubMed]

137. Doherty, M.K.; Hammond, D.E.; Clague, M.J.; Gaskell, S.J.; Beynon, R.J. Turnover of the human proteome: Determination of protein intracellular stability by dynamic SILAC. J. Proteome Res. 2009, 8, 104-112. [CrossRef] [PubMed]

138. Sadoul, K.; Boyault, C.; Pabion, M.; Khochbin, S. Regulation of protein turnover by acetyltransferases and deacetylases. Biochimie 2008, 90, 306-312. [CrossRef] [PubMed]

139. Katsogiannou, M.; Andrieu, C.; Rocchi, P. Heat shock protein 27 phosphorylation state is associated with cancer progression. Front. Genet. 2014, 5, 346. [CrossRef] [PubMed]

(C) 2019 by the authors. Licensee MDPI, Basel, Switzerland. This article is an open access article distributed under the terms and conditions of the Creative Commons Attribution (CC BY) license (http://creativecommons.org/licenses/by/4.0/). 